Lithuanian Culture Research Institute

rolandaskregzdys@gmail.com

\title{
ONYMS AND APPELLATIVES OF ONOMASTIC ORIGIN OF THE DICTIONARY OF POLISH LOANWORDS IN LITHUANIAN
}

K e y w o rd s: onyms, Polonisms, loanwords, Dictionary of Polish Loanwords in Lithuanian

\author{
FORMAL DISTRIBUTION OF THE ONOMASTIC FORMS \\ OF THE DICTIONARY OF POLISH LOANWORDS IN LITHUANIAN
}

Just like appellatives, the onomastic forms of different types are to be classified primarily on the basis of merely formal analysis - on internal reconstruction ${ }^{1}$ and typology as well as on the results of the assignment of a given word to the group of Polish loanwords in Lithuanian.

Due to the peculiarities of morphological and semantic structure of the onomastic forms of the loanwords in the Dictionary of Polish Loanwords in Lithuanian (DPLL) two main groups are to be distinguished: 1) virtual or genuine proper names; 2) appellatives or substituted forms of onomastic origin (predetermined by partial or complete process of appellativisation (resp. Appellativierung)).

\section{VIRTUAL OR GENUINE PROPER NAMES IN THE DPLL}

Virtual or genuine onomastic forms of the $1^{\text {st }}$ group can be subdivided into two types of proper names:

(I) personal names -

Iškariotas 'Iscariot' Sk 145

$\leftrightarrow$ g.n. ${ }^{2}$ OPol. Iskariota, MPol. Iskaryota 'Iscariot' ( $\leftrightarrow$ g.n. [Old/Middle] Pol. Judasz Iskaryota 'ditto'< p.n. L. Jüdas Iscariotes 'Judas Iscariot' $\leftarrow$ g.n. Gk. [E.B.P.]

${ }^{1}$ The research on loanwords (as well as on inherited lexicon) of the Lithuanian language should be based on a methodology that ensures great reliability and cogency. The analysis of lexemes is to be based on the inner reconstruction methodology, i.e.: a detailed phonetic (or phonological), morphological, and semantic analysis should be performed first. And only after the establishment of the integral structural elements has been done, these elements are to be compared with their equivalents in cognate languages, wherein the method of external (or historical) reconstruction should be taken into account.

${ }^{2}$ See the list of abbreviations at the end of the paper. 


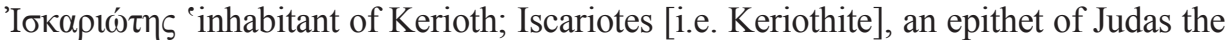
traitor' $\leftarrow$ OHeb. 'iš 'a man [vir]' + top. OHeb. Qirya 'Kiryat, a city located in the North District of Israel on the western slopes of the Hula Valley near the Lebanese border, adjoining the city of Hevron') — the origin of the fricative consonant $-\check{s}$ - is to be explained in two ways: 1) as an authentic appellative of onomastic origin of the Semitic form, or 2) analogous with g.n. / nickname Pol. Judasz /-aś/ 'Judas; a traitor' (SL ibid.), but not by the impact of g.n. Pol. \$ Iszkariot (such a form, missing in Polish written sources of different periods, was indicated by P. Skardžius [see Sk 145]),

Judõšius ‘Judas' Sk 149

$\leftarrow$ p.n. (Old / Middle) Pol. Judasz 'Judas; a traitor' (< p.n. OCz. Judáś ‘ditto’ < g.n. L. Jüdas 'Judah, a son of Jacob and patriarch of one of the tribes of Israel;

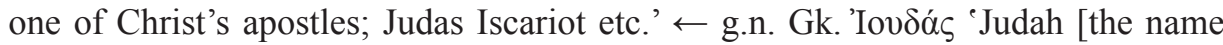
of ten Israelites; also of the posterity of one of them and its region]' $\leftarrow$ g.n. OHeb. Yəhūdāh 'son of Jacob and Leah; tribe descended from Judah etc.' $\leftrightarrow$ 'praised, object of praise').

Maižiešius 'Moses' Sk 183

$\leftarrow$ g.n. (Old / Middle) Pol. Mojżesz 'Moses' $\leftrightarrow$ MPol. Mojżeszowe prawo 'the Law

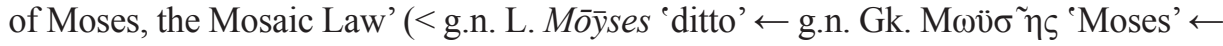
g.n. Old / Middle Heb. Mōšeh 'Moses, the great Hebrew leader, prophet and lawgiver [? $\leftarrow$ OHeb. $m \bar{a} \bar{s} \bar{o} y$ '“drawn out of the water"]').

And (II) to p on y m s -

Francija 'France' Sk 131

$\leftarrow$ top. MPol. Francya (Pol. Francja) 'France' (< top. ML. Francia 'ditto') $\rightarrow$ top. Bel. Фра́нц̧ыя ‘ditto', top. Russ. Фра́нциия 'ditto'.

**Grecija 'Greece' Sk 135

$\leftarrow$ top. MPol. Grecya, top. Pol. Grecja 'Greece, Hellas’ (< top. ML. / L. Graecia 'Hellas') $\rightarrow$ top. Bel. Грэиьыя 'Greece', top. Russ. Гре́ичия 'ditto'.

Hišpanija 'Spain' Sk 141

$\leftarrow$ top. (Middle) Pol. Hiszpania 'Spain' (< top. L. Hispānia 'ditto’).

Infliantai 'Livonian Voivodeship' Sk 143

$\leftarrow$ top. (v.) le. Inflanty 'Livonian Voivodeship' (< top. G. Livland 'Livonian County').

Jerozolima ‘Jerusalem' Sk 148

$\leftarrow$ top. (Middle) Pol. (dial.) Ierozolima (MPol. Hierozolima) 'Jerusalem' (< top.

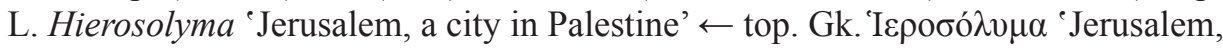
a capital of the Kingdom of Judah' $\leftarrow$ top. Medieval/Old Heb. Yorūšāláyim 'Jerusalem').

Jerùzalè 'one of the most known cities in Palestine, the chief centre of Judaism and Jewish history' LE IX: 388-392.

$\leftarrow$ top. Pol. dial. (ŽV-Md) Jeruzalem, Jeruzale 1783 'Jerusalem' — for more details about word origin see Jerozolima. 
Lipskas 'Leipzig’ Sk 179

$\leftarrow$ top. (Middle) Pol. Lipsk 'Leipzig' ( $\leftrightarrow^{3}$ top. ML. Lipsia 'ditto').

Švecija 'Sweden' Sk 277

$\leftarrow$ top. MPol. Szwecya, Pol. Szwecja 'Sweden' (< top. ML. Suecia 'ditto') $\rightarrow$ Bel. Шве́иья 'Sweden', Russ. Шве́иия 'ditto'.

Some of the said toponyms are to be attributed to the group of the loan type of semipolonisms (e.g., Francija, Grecija [see schema; also see section 2] — they are marked with two asterisks resp. ${ }^{* *}$ ). Both of them are polonismslatinisms ${ }^{4}$ (of the different period of time) borrowed in Lithuanian.

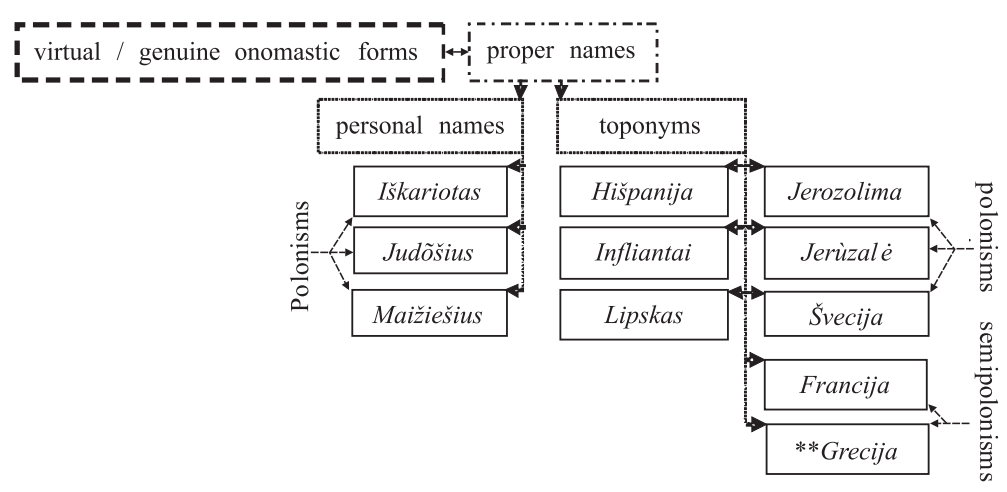

Correlation of the genuine onomastic forms of DPLL

\section{APPELLATIVES OR SUBSTITUTED FORMS OF ONOMASTIC ORIGIN IN THE DPLL}

Given the outcomes obtained by comparative analysis of the formal (i.e., identification of the composition of lexical semantic groups in different IE or other languages) and pragmatic or derivational (the existence of elements of the identical or similar morphological structure) methods 5 , appellatives or substituted forms of onomastic origin of the DPLL are to be divided into three groups. Distribution is also based on the principles of $(\alpha)$ the establishment of the primary source of the variants of the Lithuanian form (through areal distribution), and ( $\beta$ ) the words' phonetic, morphological and semantic identity (correlated with the modulation of $\alpha$ ). 202).

3 The Slavic origin of the toponym is to be presupposed (for more details see Филичева 2003:

${ }^{4}$ Such a presumption is to be made under to the following criteria:

1) by virtue of the formal usage, i.e. in accordance with the identical morphological and semantic status of the lexemes of Polish and Latin origin, the obligatory dialectal usage of these borrowings should be stated;

2) because of structural conformity/discrepancy;

3) by means of semantic congruity/contrariety (for more detaisl see Kregždys 2014: 407, 414-415; 2016: 83-85).

${ }^{5}$ For more details see Kregždys 2016: 24-95. 
Also taken into account are peculiarities in the usage of the primary forms (not necessarily in the inherited layer) on the West Slavic ground, and their secondary variants in the East Slavic languages (based on the influence of factors $\alpha$ and $\beta$ ). The resulting three groups are:

I. monogenic (i.e. homogenous, not represented in the vocabulary of the East Slavic languages (based on factor $\alpha$ )),

II. indeterminate (due to the presence of variants of loanwords from Polish in East Slavic vocabulary (factor $\alpha$ ) in different time periods),

III. alternative (III.1. forms belonging to the inherited layer, characteristic of Polish and one of the East Slavic languages (with regard to factor $\alpha$ ); III.2. doublet variants of foreign origin, derived from a different primary source; III.3. semipolonisms).

In accordance with the etymological substratum of the borrowings the first group are subdivided into 10 classes: 1) examples of Slavic inherited lexicon (krakoviánka, mazūras); 2) loans of Germanic origin (angelskas, infliančikas, karazè, kondratas, liùteras, sãsas, taliorius); 3) words of Latin origin (blažeikas, bernadỹnas, kartūzas); 4) lexemes of Greek origin (matéika, herodijonas, macedonijonas, malmozija, pivanija); 5) words of Semitic origin (adamaškas, adamaškinis, babilonskas, bartkus, galijõtas, izraelskas, jezuvita [s], kamùila, lazarètas, maceikà, nazareñskas, simoniokas, sodomčikas); 6) loans of Celtic origin (ãrosas, cãlünas); 7) Turkish borrowings (baneliukas); 8) arabisms (karabẽle, machametonas); 9) loans from Hungarian (kóčas); 10) borrowings from Indian (tabokà).

The $2^{\text {nd }}$ group of appellatives or substituted forms of onomastic origin in the DPLL (with the different localization of appellativisation process [see table]) is to be subdivided into three types:

(I) appellatives of the personal names -

bartkus ‘a tailor' LKŽe

$\leftrightarrow$ (Middle) Pol. (dial.) bartek ${ }^{~}$ commoner, redneck, ribald; eddy, vortex; element in a loom or spinning-wheel; a tall man' ( $\leftarrow$ [hypocoristic forms of given names] OPol. Bartak 'ditto' / MPol. Bartek 'ditto’ $\longleftarrow$ g.n. [Old/Middle] Pol. Bartłomiej 'ditto' $\longleftarrow$ g.n. OF. Barthelemieu 'ditto’ $\longleftarrow$ g.n. L. Bartholomaeus 'Bartholomew' $\longleftarrow$ g.n.

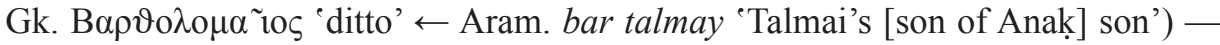
designation of a craftsman with an associative connotation ${ }^{6}$.

bernadỹnas 1. 'a monk of the Franciscan order'; 2. 'a plant of Buttercup Family — Ranunculaceae, monkshood (Aconitum Stoerkianum)' LKŽe.

$\leftarrow$ (Middle) Pol. Bernadyn 'Franciscan, a monk of the Franciscan order etc.' $(\leftrightarrow$ [Middle] Pol. Bernardyn 'ditto' < ML. Bernardinus 'Bernardine, a monk of Cistercian order' $\leftarrow$ g.n. ML. Bernardus Claraevallensis 'St. Bernard of Clairvaux, a French abbot, Saint, Doctor of the Church') $\rightarrow$ OBel. бернадынъ, бернадинъ 'a monk of St. Bernard of Clairvaux order'.

${ }^{6}$ Cf. expression of Lithuanians: Veją ir siuvejja sunku pagaut Prn, i.e. To catch a wind is as difficult as to land a sewer (LKŽe [see in loco siuvejas $(-i s,-u s),-a]$ ). 
blažeikas 'Ground-hog Day candle; handmade candle' LKŽe.

$\leftarrow$ MPol. błaziejek ([Middle] Pol. błażek) 'a wax roll is to be put on the candle; an instrument used to extinguish burning candles' ( $\leftarrow$ g.n. [Old/Middle] Pol. Btażej 'St. Blaise - bishop of Sebastea, was martyred by being beaten, attacked with iron combs, and beheaded [ $\nmid 316]^{\prime}<$ p.n. L. Blasius 'a type of surname' $[\rightarrow$ g.n. Gk. (E.B.P.) $\mathrm{B} \lambda \alpha \sigma i \omega v$ 'ditto'] $\leftarrow$ nickname [cognomen] L. Blaesus 'Blaise, a surname [nomen paternum] of the Julii and Sempronii Roman families' $\leftarrow$ L. blaesus 'lisper; stammerer').

galijõtas ‘a giant, strongman' LKŽe.

$\leftarrow$ MPol. golijat (Pol. goljat) 'a giant, a tall man' ( $\neq$ g.n. MPol. Goliat 'Goliath of Gath, a giant Philistine warrior defeated by the young David, the future king

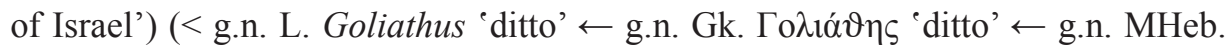
Golyat 'Philistine warrior from the city of Gath' $\leftarrow$ g.n. OHeb. Golyat 'Philistine giant slain by David; Goliath'),

$\| \neq$ g.n. OCS. (Russ.) Голіа́ ‡ъ 'Goliath, a giant Philistine warrior'

**herodijonas, $-\dot{\boldsymbol{e}}$ 'a follower of Herod' LKŽe; Sk 141

$\leftarrow$ MPol. herodyjan 'a follower of Herod, doer of his will, the adversaries of Pharisees' $(<\mathrm{L}$. Hèrōdiāni 'ditto' $\leftarrow$ Gk. 'H $\rho \omega \delta$ dıvoí 'the followers of Herod' $\leftarrow$ g.n.

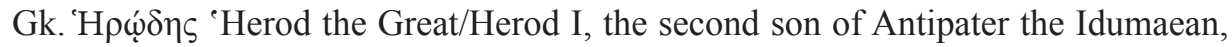
a Roman client king of Judea [37 BCE-4 BCE]').

jezuvita(s) 'Jesuit' Sk 149

$\leftarrow$ (Middle) Pol.jezuwita 'Jesuit, a member of the Society of Jesus (S.J.), a Roman Catholic order of religious men founded by St. Ignatius of Loyola; indrawn, plotter' ( $<$ F. jésuite 'Jesuit; snake (about human), trickster' $\leftarrow$ ML. jesuitus 'Jesuit' $\leftarrow$ g.n. L. Jēsus, Iēsus 'Christ the Redeemer; Yeshua' $\leftarrow$ g.n. Gk. [E.B.P.]'Inбoús 'ditto' $\leftarrow$ g.n. LBHeb. Yešša 'Jeshua [a Hebrew name]' $\leftarrow$ g.n. OHeb. Yəhōšü ${ }^{a}$ ' 'Moses' successor) [ $\leftarrow$ 'God — salvation'], son of Nun; governor of Jerusalem under Josiah; head of one of the classes of priests etc.') $\rightarrow$ OBel. езувить 'Jesuit'.

kamùila 'uneducated, untidy, scruffy man; ribald, lout' LKŽe.

$\leftrightarrow$ Pol. dial. (ŽV-Md [Degucie]) chamujto 'tyke, oik, peasant' ( $\leftarrow$ [Middle] Pol.

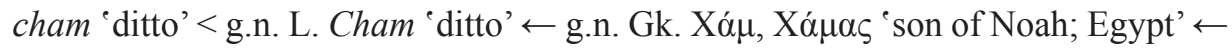
g.n. OHeb. Hām ' $2^{\text {nd }}$ son of Noah; called father of Canaan') $\rightarrow$ Bel. dial. хамуйла 'ribald, oik, gruff man' $\rightarrow$ Bel. dial. хамула 'loser'.

kondratas 'tormentil (Potentilla erecta)', kondrotas 'ditto' LKŽe.

$\leftrightarrow$ Pol. dial. kondratek 'plant of the Labiatae family; wallflower, a genus of flowering plants in the botanical family Brassicaceae; catmint; the ivy plant etc.' ( $\leftarrow^{7}$ [Middle] Pol. konrad 'the ivy plant; wallflower, a genus of flowering plants in the botanical family Brassicaceae etc.' $<$ g.n. [Old/Middle] Pol. Konrad 'ditto' $\leftarrow$

7 The origin of the structural element $-d$ - is to be related with the contamination of proper names (Old/Middle) Pol. Konrad and (Old/Middle) Pol. Kondrat ' Conrad' (< surname L. Quadrātus 'a Roman surname' $\leftarrow$ L. adj. quadrātus 'quadrangle' [LSh 1499]), such cases are found in the Old Polish scripts (for more details see SEMot II: 72). 
g.n. G. Konrad/OHG. Conrad 'Conrad' $\leftarrow$ OHG. kuoni 'brave; wise; strong; power, kick' + OHG. rât 'counsil; decision').

lazarètas 'hospital' ZtŽ 344; lazariẽtas 1. 'ditto'; 2. 'an ailing person' LKŽe; SŽ 336

$\leftarrow$ (Middle) Pol. (dial.) lazaret, Pol. dial. tazaret 'madhouse; (war) hospital' ( $<$ G. Lazaret 'hospital' / F. lazaret 'hospital; quarantine' / It. lazzaretto 'isolation hospital' $\leftarrow$ ML. lazarus 'leper' $\leftarrow$ Gk. [E.B.P.] $\lambda \alpha$ Cóópıv 'lazar-house; hospital' $\leftarrow$ I Gk. $\lambda \alpha \dot{\zeta} \alpha \alpha \rho \varsigma^{~ ' a ~ c o r p s e ~[f r o m ~ L a z a r u s ~ o f ~ B e t h a n y, ~ t h e ~ b r o t h e r ~ o f ~ t h e ~ s i s t e r s ~ M a r y ~ a n d ~}$ Martha, restored to life by Jesus, who made a visit to the house of Simon the Leper at Bethany during the course of which a woman anointed the head of Jesus with costly

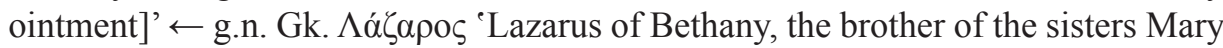
and Martha' $\leftarrow$ g.n. OHeb. 'El 'äzor 'God is my help'; Aaron's third son, after his death, Eleazar was appointed high priest in his father's place; a son of Moses; Levite chief etc.') $\rightarrow$ Bel. лазарэт 'hospital for the poor; a small war hospital'.

liùteras, $-\dot{\mathbf{e}}$ 'a member of a Western Christian church adhering to the theology of Luther' LKŽe; SŽ 350; liùtras, - $\dot{e}$ 'ditto' LKŽe.

$\leftarrow$ (Middle) Pol. luter 'a member of a Western Christian church whose faith and practice are founded on the principles of the Protestant Reformation; Lutheran, Protestant etc.' (< g.n. G. Luther 'Martin Luther, a seminal figure in the Protestant Reformation') $\rightarrow$ OBel. люторь, лютаръ, лютрь 'a member of a Western Christian church whose faith and practice are founded on the principles of the Protestant Reformation; Lutheran, Protestant', Bel. лютар 'ditto', ORuss. люторь, люторь, лютар в 'ditto'.

**macedonijonas 'Macedonian resp. a follower of Macedonius, bishop of Constantinople' Sk 182

$\leftarrow$ MPol. Macedonijan 'a follower of Macedonius, bishop of Constantinople, a doer of his instructions, heretic' $(<$ ML. Macedonianus 'ditto' $\leftarrow$ Gk. [E.B.P.]

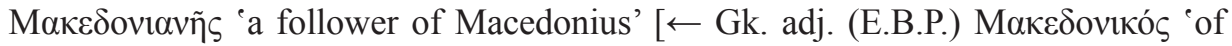

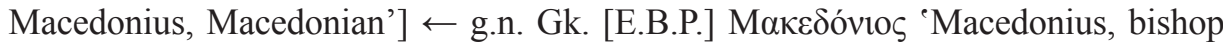
of Constantinople').

maceikà, macéika 'timothy grass (Phleum pratense)' LKŽe.

$\leftrightarrow^{8}$ Pol. maciejka 'gillyflower; Vigil of Saint Matthew etc.' ( $\leftarrow$ surname MPol. Maciejanka 'Polish surname [referring to a female]' $\leftarrow$ g.n. [Old/Middle] Pol. Maciej 'ditto' $<$ [ $\leftarrow$ OF. matthiole 'gillyflower [Matthiola incana], a species established by Robert Brown'] g.n. [Old] F. Matthieu 'Matthew' $\leftarrow$ g.n. L. Matthaeus

${ }^{8}$ The authors of LKŽ(e), for some reason, ignored different assibilation characteristics of $t$ consonant (such cases are found in dialectisms, i.e. lexemes used in Lithuanian subdialects (for more details see Zinkevičius 1966: 139-140)). Therefore, they ascribed the words of different genesis to the same lexical-semantic group, cf.:

1) Lith. dial. maceikà 2 (bot) 'timothy grass (Phleum pratense)' from the area of southern Highlanders (subdialect of Liškiavos [dialect № 687]), which is characterized by the process of assibilation $t>c$ (see 


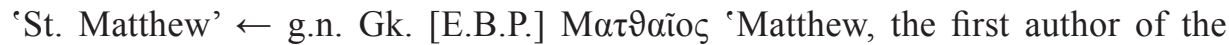
Gospel' $\leftarrow$ OHeb. mattitya $\bar{a} h \bar{u}$ 'gift of YAHWEH'; a Levitical musician; Levitical name; attendant of Ezra (also Levite?); one of those who took strange wives') $\rightarrow$ Bel. маце́йка 'gillyflower; hoary stock (Matthiola incana R. B.)' — also see matéika, motéika.

machametonas 'Muslim' Sk 182

$\leftarrow$ (Middle) Pol. mahometan 'a believer in or adherent of Islam; following the religion of the prophet Muhammad' (<F. mahométan 'Muslim' $\leftrightarrow$ g.n. F. Mahomet 'Mohammed, an arab prophet of Islam'/OF. mahomet 'idol, god; favourite' $\leftarrow$ g.n. Arab. Muhammad 'Muhammad; Venerable, glorious').

matéika 'timothy grass', motéika 'ditto' ŠVŽŽ I: 420

$\leftarrow$ Pol. dial. matejka 'timothy grass (Phleum pratense)' ( $\leftarrow$ Pol. trawa Św. Tymoteusza ‘timothy grass' $\leftarrow$ g.n. Pol. Tymoteusz 'ditto’ < g.n. L. Timotheus ‘dit-

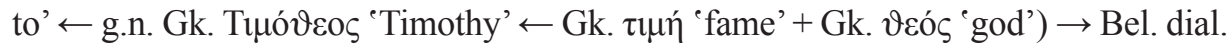
матэйка 'perennial grass that can be fed to cattle' — also see maceikà, macéika.

simoniokas 'a man who attempts to buy or sell an office of the Church or a sacrament' Sk 255

$\leftarrow$ (Middle) Pol. symonjak 'a man who attempts to buy or sell an office of the

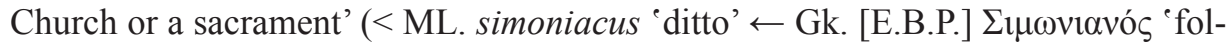
lower of Simon the Sorcerer' $\leftarrow$ g.n. Gk. [E.B.P.] $\Sigma$ í $\mu \omega v$ 'Simon, the magician from Samaria' ApD $8.9 \leftarrow$ g.n. OHeb. Šm 'ōn 'second son of Jacob and Leah $[\leftarrow$ "He (God) has heard']; tribal name; Jew with foreign wife') $\rightarrow$ OBel. симониякь 'a man who attempts to sell an office of the Church or a sacrament'.

(II) a ppellatives of toponyms -

adamaškas 'a type of inwrought silk fabric; damask (fabric)' LKŽe.

$\leftarrow$ (Old/Middle) Pol. adamaszek 'heavy inwrought silk fabric etc.' (Pol. dial. adamasek 'flat fabric with a wet-look on the wrong side v.v.') (< ML. adamaschus 'Damascian, of Damascus' / It. [da] damasco 'silk fabric [from Damascus]' $\leftarrow$ top. L. Damascus 'ditto’ $\leftarrow$ top. Gk. $\Delta \alpha \mu \alpha \sigma \kappa o ́ \varsigma$ 'Damascus, the capital of Syria’ $\leftarrow$ top. OHeb. Damméseq 'ancient Aramaean city'/top. Egypt. Temesqu 'Damask') $\rightarrow$ OBel. адамашокъ, одамашокъ 'silk fabric from Damascus’ $\mathbb{O}$ OBel. адамашка, одамашка, одомашка 'ditto', Bel. адама́шка 'inwrought silk fabric', ORuss. адамашка, одамашка 'silk fabric from Damascus'.

Zinkevičius 1966: 139), is to be related to Pol. dial. matejka 'ditto' (SW VII: 189) $\leftarrow$ Pol. trawa Św. Tymoteusza 'timothy grass (Phleum pratense)' (see 1.c. matéika, motéika) - hypocoristic form (also cf. clipping form of Pol. dial. mateuszka 'timothy grass' [SW II: 902]) was related to -

2) the lexeme of totally different semantic value (in terms of the etymological analysis) used in the subdialects of Kaunas in Balbieriškis (dialect № 609 - an area of western Highlanders) with no $t$ assibilation trends (see Zinkevičius ibid). Due to the comparison of the structural elements -mat- / -mac- with partial homonymy, the sememe of the different plant name (i.e. 'timothy grass') was erroneously related to Pol. ma-c-iejka 'gillyflower', which presupposes etymological reference with the g.n. Gk. [E.B.P.]

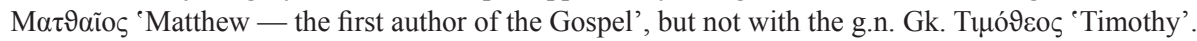


adamaškinis, - $\dot{\mathbf{e}}$ 'made of damask (fabric)' LKŽe

$\leftrightarrow$ (Old/Middle) Pol. adamaszkowy 'of heavy inwrought silk fabric etc.' $\rightarrow$ OBel. адамашковый, адомашковый, одамашковый, одомашковый 'of silk fabric from Damascus' - for more details about lexemes origin see adamaškas.

angelskas, -à 'English' ZtŽ 53

$\leftarrow$ (Middle) Pol. angielski 'English' $\leftrightarrow$ ML. Anglicus 'English' $\leftarrow$ top. L. Anglia 'England' $\leftarrow$ top. OE. Englaland 'country of the Angles') $\rightarrow$ OBel. анкгельский, ангелский, анкгелский 'English', Bel. (dial.) анге́льскі 'ditto'.

ãrosas 'one of a kind yarns' LKŽe

$\leftarrow$ Old/Middle Pol. (dial.) aras ([Old / Middle] Pol. [dial.] haras) 'soft, coarse wool fabric used for backing' (< MHG. arra3, arras, harras 'soft wool fabric'/ G. Arras, Harras 'production of high quality wool [tapestry]' $\leftarrow$ top. F. Arras 'a city in Northern France, known for its tapestries of the highest quality') $\rightarrow$ $\mathbb{C}$ OBel. zарусъ 'thin wool fabric', Bel. zápyc 'wool fabric', Russ. zápycъ 'stranded white or coloured wool; wool yarns in stranded knitting'.

babilonskas 'Babylonian' Sk 94

$\leftarrow$ MPol. Babilonski, Pol. babiloński 'Babylonian' (< L. Babylōnicus 'ditto' top. L. Babylōn 'ditto' $\leftarrow$ top. Gk. B $\alpha \beta v \lambda \omega$ v' ditto' $\leftarrow$ top. OHeb. Bābél 'Babylon, the ancient capital of Babylonia' $\leftarrow$ Akkad. bāb-ili $[m]$ 'Babylon [ $\leftarrow$ 'gate of god']').

baneliùkas 'gossip / wind, trifle' LKŽe

$\leftrightarrow$ Pol. (dial.) banialuka 'cheap, meaningless book; gossip/wind, trifle; folly' $(<$ top. Serb. Баิња̄ Лýка 'one of the most important localities in Bosnia, where was the residence of Bosnian pasha' $\leftarrow$ OTurk. bajan 'higher military rank').

calūnas, cãlūnas 'hearse cloth' LKŽe

$\leftarrow$ (Old/Middle) Pol. calun 'a big cover; a black hearse cloth, crape; bedspread; coarse baize; sleazy clothing of a monk etc.' (< OCz. čalún 'most expensive textile; a cover' $\leftarrow$ top. G. Schalun 'ditto' $\leftarrow$ top. F. Châlons 'locality in the department of Isère').

infliančikas 'inhabitant of Livonian Voivodeship"9 Sk 143

$\leftarrow$ MPol. Inflanczyk, Inflantczyk 'inhabitant of Livonian Voivodeship; a member of The Livonian Order, resident of Livonian County' ( $\leftrightarrow$ MPol. Inflant / Liwlant 'ditto' $\leftarrow$ G. Livländer 'inhabitant of Livonian County' $\leftrightarrow$ top. G. Livland 'Livonian County').

izraelskas, $-\boldsymbol{a}$ 'of Israel, Israelian' LKŽe

$\leftarrow$ (Old/Middle) Pol. izraelski 'Israelians, Israelian' (< I. Yid. adj. yisreéiliš 'of Israel, Israelian' $\leftrightarrow$ top. Yid. Yisroél 'Israel' $\leftarrow$ top. OHeb. Yisrā 'el 'Israel [name

${ }^{9}$ Livonian region (resp. top. Pol. Polskie Inflanty) in historiography commonly referred to as Livonian County until 1772 y., i.e. until the First Partition of the Polish-Lithuanian Commonwealth, although the Livonian Language was termed as Pol. język inflancki (SpXVI VIII: 542). The area, also called the Livonian Voivodeship, extended to the right bank of the river Daugava (for more details see LE VIII: 503). 
of Hebrew nation $] \leftarrow$ "God contended"”; II. top. L. Isrāel 'Israel’ $\leftarrow$ top. Gk.

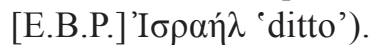

\section{karabẽlè ‘falchion' LKŽe}

$\leftarrow$ (Middle) Pol. karabel $(l) a$ 'falchion with an ornate hilt' (< top. Arab. Karbala 'an area in Arabia') $\rightarrow$ OBel. корабеля 'falchion'.

karazè 'coarse homespun'; karazia 'ditto' LKŽe

$\leftarrow$ MPol. karazyja (Pol. karazja) 'ordinary (cheap), coarse wool texture' (< G. Karsai, Kirsei 'coarse homespun' $\leftarrow$ ME. kersei 'wool fabric used for pants; twill; twill clothing' $\leftrightarrow$ top. E. Kersey 'an area in the South East England') $\rightarrow$ OBel. каразыя (каразъя) 'coarse texture’ $\mathbb{L}$ Russ. каразе́я 'coarse wool texture used as backing'.

kartūzas 'a monk of the Carthusian order' Sk 156

$\leftarrow$ (Old/Middle) Pol. kartuz 'a monk of the Order of Saint Bruno of Cologne' (< top. ML. Cartusia 'Chartreuse' $\leftarrow$ top. F. Chartreuse 'Chartreuse Mountains' < L. carcer 'prison etc.') $\rightarrow$ OBel. карmyзъ 'a monk of the Order of Saint Bruno of Cologne'.

kóčas 'a type of cart; chaise' LKŽe; SŽ 306

$\leftarrow$ (Middle) Pol. kocz 'caravan, chaise etc.' (< Hung. kocsi 'a cart' $\leftarrow$ top. Hung. Kocs 'an area in Hungary where carts of many types were produced') $\rightarrow$ Bel. dial. коч 'caravan'.

krakoviánka ‘Cracow region folk dance, the Krakowiak’ DvŽ I: 304

$\leftrightarrow$ Pol. dial. krakowian 'Polish folk dance; folk music of the dance' ( $\leftarrow$ top. [Old / Middle] Pol. Kraków 'Krakow') $\rightarrow \mathbb{C}$ Bel. (dial.) кракавяк, Bel. dial. кракавяка 'Polish folk dance' — the lexeme made up of the suff. - $k a$ because of contamination with the Lith. pol-ka a vivacious couple dance of Bohemian origin in duple time; folk music of the dance'.

malmozija 'malvasia (a type of wine)' Sk 184

$\leftarrow$ MPol. malmazyja, Old / Middle Pol. małmazyja (Pol. małmazja) 'saldus graiku vynas' (<ML. malmasia 'a type of red wine' / MHG. malmasîer / It. malvasia 'variety of red grapes; red grape wine' $\longleftarrow$ top. It. Malvasia 'locality near Neapolis') $\rightarrow$ OBel. малмазия, малмазыя (малмазэя) ‘a type of wine' $\mathbb{H}$ ORuss. малмазгья 'ditto'.

nazareñskas ‘Nazarene’ Sk 195

$\leftarrow$ (Middle) Pol. nazareński ${ }^{~ N a z i r i t e, ~ o n e ~ w h o ~ h a s ~ v o l u n t a r i l y ~ d e d i c a t e d ~ h i m s e l f ~}$ to God; designation of Jesus Christ; Christian' ( $<$ L. Nazarēnus 'Nazarene; one who

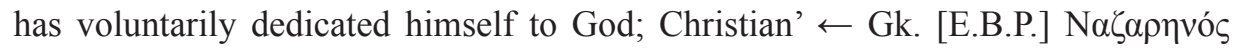

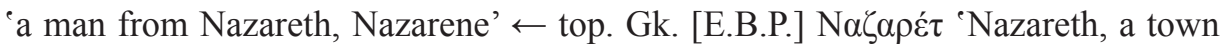
in Galilee' $\leftarrow$ MHeb. nōcrī 'Nazarene; Jesus' $\leftarrow$ top. MHeb. Nocrat $)$ 'Nazareth'/ OHeb. nāzīr 'one consecrated, devoted [God's devotee]; a ruler; one who has voluntarily dedicated himself to God, ascetic; untrimmed vine').

pivanija 'peony (Paeonia)'; pivõnija, pivònija 'ditto' Sk 228; LKŽe; also see ZtŽ 488 


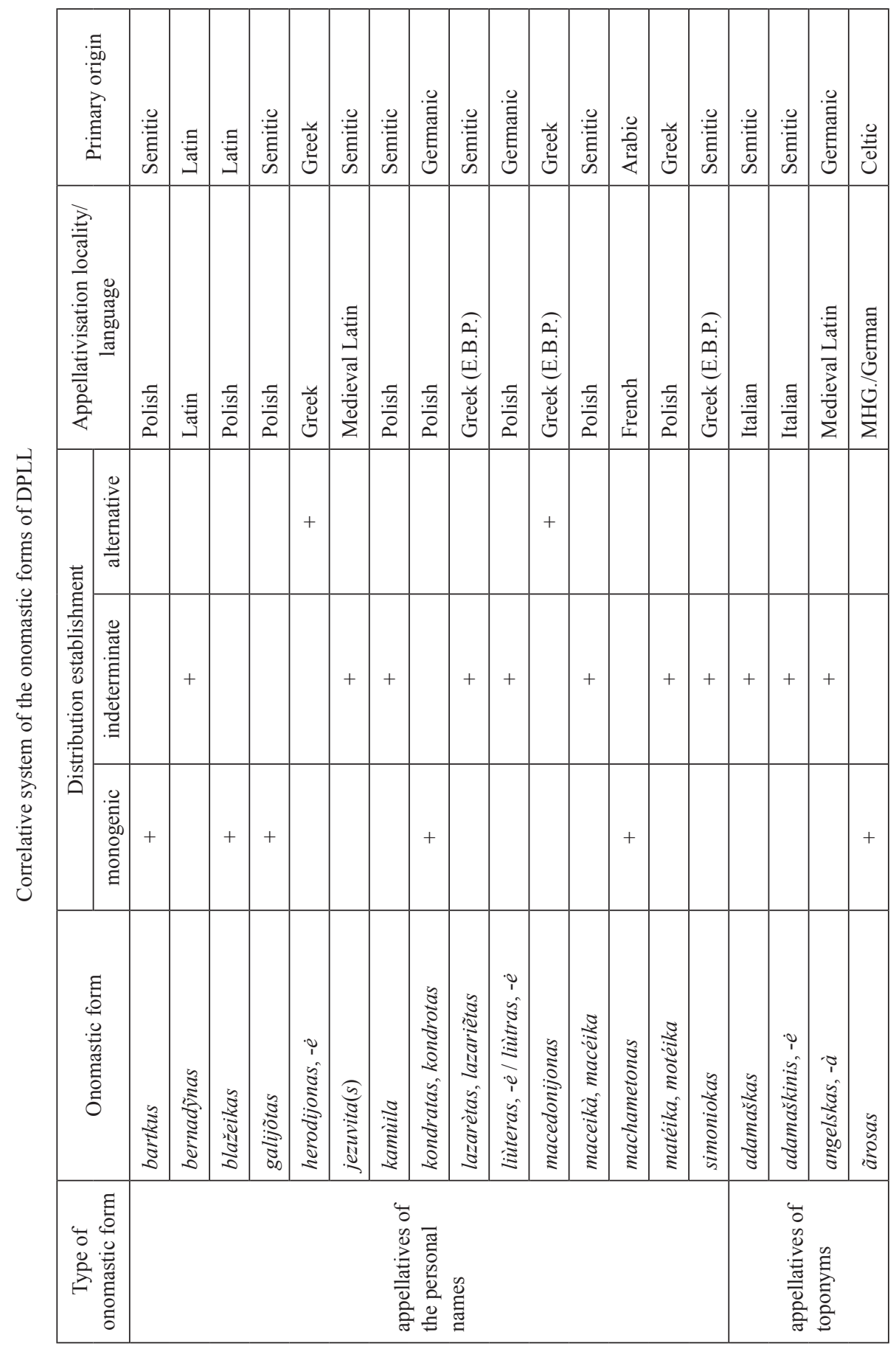




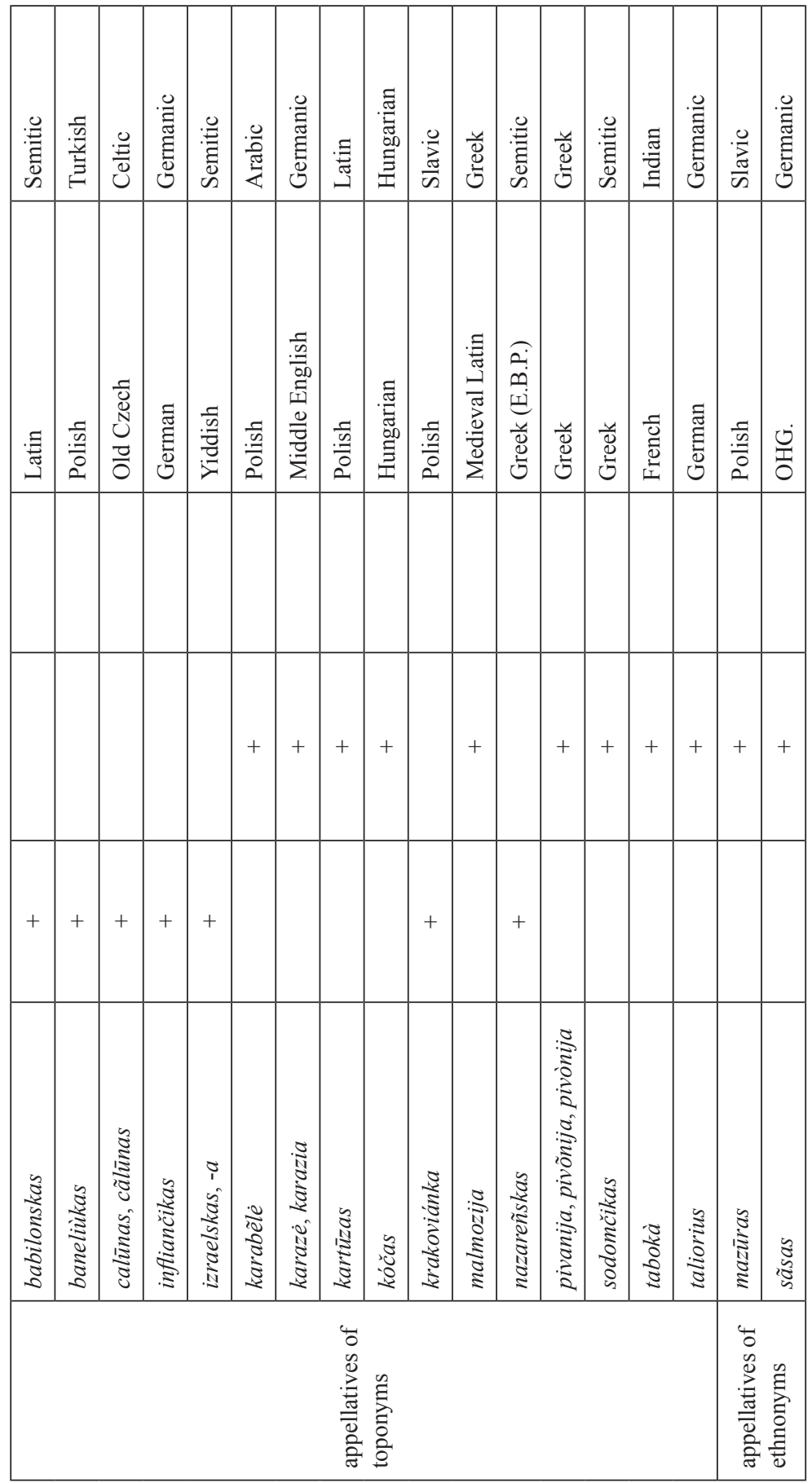


$\leftarrow$ Old/Middle Pol.piwonija (Pol.piwonja) 'a flowering plant in the genus Paeonia, the only genus in the family Paeoniaceae (Paeonia officinalis L.) ' $(<$ L. paeonnia 'ditto' $\leftarrow$ Gk. $\pi \alpha 1 \omega v i ́ \alpha$ 'peony' $\leftarrow$ top. Gk. Maıvía 'locality in Macedonia') $\rightarrow$ Bel. (dial.) піво́нія 'peony (Paеonia L.)', Russ. пиво́нія 'ditto'.

sodomčikas 'an inhabitant of Sodom' Sk 261

$\leftarrow$ (Middle) Pol. Sodomczyk 'an inhabitant of Sodom; (in these days) paedophile; a passive, effeminate male homosexual (birdie)' $(<$ L. Sodomìtae [pl.] 'ditto' $\leftarrow$

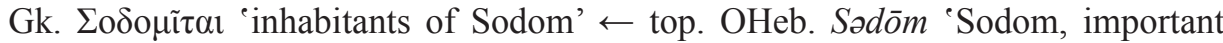
Canaanitish city named [usually] with Gomorrha') $\rightarrow$ OBel. содомчикъ 'an inhabitant of Sodom'.

tabokà 1. 'a genus of herbaceous plants and shrubs of the family Solanaceae (Nicotiana)'; 2. 'the products from the plant used for smoking, chewing, snuffing or drinking'; 3. 'corn smut (a type of fungal disease)'; 4. 'ring mark on a berry or an apple'; 5. 'snivel' LKŽe; also see ZtŽ 678.

$\leftarrow$ (Middle) Pol. tabaka, Pol. dial. (Kšbd) tobaka 'redolent fine ribbon cut tobacco' $(<$ I. G. Tabagie 'gargle factory [resp. a place where smoking is common]' F. tabagie 'gargle factory, tobacconist place; tobacco tin' $\leftarrow$ top. N.Am.Ind./ S.Am.Ind. Tabago 'locality in Yucatan / Haiti terrain of the indigenous Arhuaco tribe'; II. G. Tabak 'ditto' $\leftarrow$ F. tabac 'ditto'/It. tabacco 'ditto' $\leftarrow$ Sp. tabaco 'tobacco [Nicotiana L.]' $\leftarrow$ Araw. tábu 'to fall [e.g., mist] etc.' + Araw. áku 'an eye' resp. *'eyes having the mist' [an explanation of the plant was presented by Christopher Columbus]) $\rightarrow$ OBel. пабака 'cheap tobacco, shag (Nicotiana rustica L.)', Bel. таба́ка 'snuff, tobacco (Nicotiana tabacum L.; Nicotiana rustica L.); sharp hint', Russ. dial. таба́ка 'tobacco'.

taliorius 'a silver or gold coin of great value used in some European countries; a coin of medieval Lithuania' LKŽe.

$\leftarrow$ (Midddle) Pol. talar (taler) 'a German coin used in the Duchy of Prussia; type of game' $(<$ G. Taler 'ditto' $\leftarrow$ G. Joachimstaler 'an old German coin used until the $13^{\text {th }}$ c.' $\leftarrow$ top. Cz. Joachimstal 'locality in Czechia where the silver coins were minted') $\rightarrow$ OBel. талеръ, талярь 'silver coin; a type of measure equivalent to 1 silver thaler', Bel. (dial.) та́лер(ъ)/та́ляр 'a German coin; a silver coin of 90 copecks used in Lithuania; a coin'.

(III) a p pellatives of ethnonyms - mazüras, sãsas, cf. -

mazūras 'Masurian' Sk 186

$\leftarrow$ (Middle) Pol. mazur 'inhabitant of Masuria; a person speaking Polish; an ignorant; Masurian beer; a type of Polish folk dance etc.' ( $\leftrightarrow$ top. Pol. Mazowsze [since 1045 y.] 'Masuria' $\leftarrow$ Pol. mazia 'a swamp') $\rightarrow$ OBel. мазурь 'an inhabitant of Masuria', Bel. мáзýp(ъ) 'Masurian; a type of Polish folk dance; sleazy person; swarthy man'.

sãsas 'an inhabitant of Saxony; a member of a Western Christian church adhering to the theology of Luther, reformist' LKŽe. 
$\leftarrow$ (Middle) Pol. Sas 'Saxon' (< MLG. Sasse/OHG. Sahso 'Saxon' $\leftrightarrow$ top. Pol. Sasya 'Saxony' $\leftarrow$ L. Saxonia 'ditto') $\rightarrow$ OBel. cacb 'Saxon', Bel. cac 'ditto'.

On the basis of the analysis of the appellatives or substituted forms of onomastic origin (predetermined by partial or complete process of appellativisation) recorded in the Dictionary of Polish Loanwords in Lithuanian, the following correlative system of the loanwords can be drawn:

\section{CONCLUSIONS}

1. Two main groups of the onomastic forms of the Dictionary of Polish Loanwords in Lithuanian are to be distinguished: $\alpha$ ) virtual or genuine proper names; $\beta$ ) appellatives based on the proper nouns, i.e. appellatives or substituted forms of onomastic origin.

2. The group of virtual or genuine proper names of the DPLL is composed of two types: (I) personal names - Iškariotas, Judõšius, Maižiešius; (II) toponyms Francija, Grecija, Hišpanija, Infliantai, Jerozolima, Jerùzalè, Lipskas, Švecija.

3. The group of appellatives or substituted forms of onomastic origin of the DPLL is to be subdivided into three types: (I) appellatives based on the personal names; (II) appellatives based on toponyms; (III) appellatives based on ethnonyms.

\section{ABBREVIATIONS}

\begin{tabular}{|c|c|c|c|}
\hline adj. & — adjective & ME. & — Middle English \\
\hline Akkad. & - Akkadian & MHeb. & — Middle Hebrew \\
\hline Arab. & - Arabic & MHG. & — Middle High German \\
\hline Aram. & - Aramaic & ML. & — Medieval Latin \\
\hline Araw. & $\begin{array}{l}\text { - Arawak (one of the Arawakan lan- } \\
\text { guages in Haiti) }\end{array}$ & $\begin{array}{l}\text { MLG. } \\
\text { MPol. }\end{array}$ & $\begin{array}{l}\text { — Middle Low German } \\
\text { — Middle Polish }\end{array}$ \\
\hline Bel. & - Belarusian & N.Am.Ind. & — North American Indian \\
\hline E. & — English & OBel. & — Old Belarusian \\
\hline E.B.P. & — Early Byzantine Period & OCS & — Old Church Slavonic \\
\hline Egypt. & — Egyptian & OCz. & - Old Czech \\
\hline F. & - French & OE. & — Old English \\
\hline G. & — German (New High German) & OF. & - Old French \\
\hline Gk. & - Greek & OHeb. & — Old Hebrew \\
\hline g.n. & - given name & OHG. & — Old High German \\
\hline Heb. & - Hebrew & OPol. & — Old Polish \\
\hline Hung. & — Hungarian & ORuss. & — Old Russian \\
\hline It. & - Italian & OTurk. & — Old Turkish \\
\hline L. & - Latin & p.n. & — personal name \\
\hline Lith. & — Lithuanian & Pol. & - Polish \\
\hline LBHeb. & _ Late Biblical Hebrew & Russ. & - Russian \\
\hline
\end{tabular}




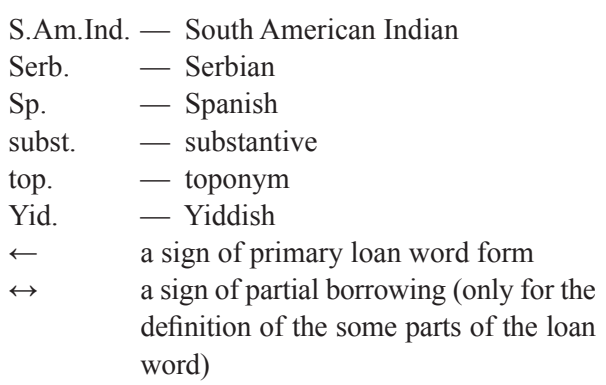

$\rightarrow \quad$ a sign of secondary borrowing (e.g., from Polish to Belarusian; from German to Polishs etc.)

$\mathbb{C}$ a sign of phonetic/morphological discrepancy

$\neq \quad$ a sign of semantic incongruity (in terms of Lithuanian lexemes)

\section{REFERENCES}

DPLL — Dictionary of Polish Loanwords in Lithuanian (Kregždys R. 2016: Lietuviu kalbos polonizmu žodynas/Stownik polonizmów w języku litewskim, „Studia Etymologica Baltica“ II, Lietuvių kalbos institutas, Vilnius).

DvŽ I-II - Dieveniškiu šnektos žodynas 1-2, (par.) Morkūnas K. and oth.., Lietuvių kalbos institutas, Vilnius 2005-2010.

Kregždys R. 2014: Lietuviu kalbos polonizmu-lotynizmu atribucijos ypatumai, [in:] M. Dawlewicz and oth. (red.), Funkcjonowanie języków i literatur na Litwie. Litewsko-polskie zwiazki naukowe i kulturowe. Monografia zbiorowa, Vilniaus universiteto leidykla, Vilnius, s. 407-421.

Kregždys R. 2016: Lietuviu kalbos polonizmu žodyno specifikacija/Charakterystyka Stownika polonizmów w języku litewskim, „Studia Etymologica Baltica“ I, Lietuvių kalbos institutas, Vilnius.

LE I-XXXVII - Lietuviu enciklopedija, 1-37, Lietuviu enciklopedijos leidykla, Bostonas 1953-1985.

LKŽe - Lietuviu kalbos žodynas, ed. G. Naktinienė and oth., t. 1-20, 1941-2002, elektroninis variantas. Antrasis elektroninis leidimas, Lietuvių kalbos institutas, Vilnius, 2013.

LSh — Lewis Ch. T., Short Ch. 1958: A Latin Dictionary founded on Andrews'edition of Freud's Latin Dictionary, Clarendon Press, Oxford.

SEMot I-VII - Stownik etymologiczno-motywacyjny staropolskich nazw osobowych, 1-7, IJP PANDWN, Kraków, 1995-2002.

Sk — Skardžius P., Rinktiniai raštai, 4, par. A. Rosinas, Mokslo ir enciklopedijų leidybos institutas, Vilnius 1998.

SL — Linde M. S. B., Stownik języka polskiego, 1-6, v Drukarni Xięży Piiarów, Warszawa 1807 1814.

SpXVI I-XXXVI... - Stownik polszczyzny XVI wieku, 1-36, Ossolineum-IBL PAN, Wrocław-Warszawa 1966-2012

SPJL — Stownik polonizmów w języku litewskim (see DPLL).

SW I-VIII — Stownik języka polskiego, 1-8, ed. J. Karłowicz J. a. oth., w drukarni E. Lubowskiego, Warszawa 1898-1923.

SŽ — Mato Slančiausko ir jo pagalbininku pasakojamosios tautosakos rinkiniu leksika: žodynas, ed. J. Švambarytė-Valužienè, Lietuvių kalbos institutas, Vilnius 2015.

ŠVŽŽ I-II - Šiaurès vakaru žemaičiu žodynas, 1-2, ed. B. Vanagienè, Lietuvių kalbos institutas, Vilnius 2015.

Zinkevičius Z. 1966: Lietuviu dialektologija, Mintis, Vilnius.

ZtŽ — Zietelos šnektos žodynas, ed. A. Vidugiris, Mokslo ir enciklopedijų leidybos institutas, Vilnius, 1998.

Филичева Н. И. 2003: История немецкого языка, Издательский центр «Академия», Москва. 


\section{ONYMS AND APPELLATIVES OF ONOMASTIC ORIGIN IN THE DICTIONARY OF POLISH LOANWORDS IN LITHUANIAN}

\section{SUMMARY}

The paper presents a build-up schedule for classification of the onomastic forms presented in the Dictionary of Polish Loanwords in Lithuanian (further - DPLL). Due to the peculiarities of morphological and semantic structure of the onomastic forms two main groups of the loanwords of DPLL are distinguished: 1) virtual proper names; 2) reflections of the proper nouns, i. e. appellatives or substituted forms of onomastic origin.

Moreover, the onomastic forms of the $1^{\text {st }}$ group are subdivided into two types of proper names: personal names - Iškariotas, Judõšius, Maižiešius, and toponyms - Hišpanija, Infliantai, Jerozolima, Jerùzale, Lipskas, Francija, Švecija, Grecija. Some of the mentioned words are to be attributed to the group of the loan type of semipolonisms (e.g., Francija, Grecija).

The $2^{\text {nd }}$ word group is the larger one. In accordance with etymological substratum of the borrowings this group is subdivided into 10 classes: 1) Slavic inherited lexicon (krakoviánka, mazūras); 2) loans of Germanic origin (angelskas, infliančikas, karazè, kondratas, liùteras, sãsas, taliorius); 3) words of Latin origin (blažeikas, bernadỹnas, kartūzas); 4) lexemes of Greek origin (matéika, herodijonas, macedonijonas, malmozija, pivanija); 5) words of Semitic origin (adamaškas, adamaškinis, babilonskas, bartkus, galijõtas, izraelskas, jezuvita[s], kamùila, lazarètas, maceikà, nazareñskas, simoniokas, sodomčikas); 6) loans of Celtic origin (ãrosas, cãlūnas); 7) Turkish borrowings (baneliùkas); 8) arabisms (karabẽle, machametonas); 9) loans from Hungarian (kóčas); 10) borrowings from Indian (tabokà). 